Economia e Sociedade, Campinas, Unicamp. IE. http://dx.doi.org/10.1590/1982-3533.2019v28n3art04

\title{
O que é superexploração? *
}

\author{
Rodrigo Straessli Pinto Franklin **
}

\begin{abstract}
Resumo
O que é a superexploração da força de trabalho? Como a superexploração funciona? Quais são seus impactos para a classe trabalhadora? O presente artigo busca responder a essas questões, demonstrando como a categoria introduzida por Ruy Mauro Marini pode ser compreendida em acordo com a teoria marxista do valor, e como ela se articula com a determinação do valor da força de trabalho. O texto foi elaborado tendo em vista tanto contribuir para uma compreensão mais ampla dessa categoria quanto para apresentá-la àqueles que não são conhecedores do debate sobre a dependência.
\end{abstract}

Palavras-chave: Superexploração; Teoria da Dependência; Teoria do Valor.

\section{Abstract}

\section{What is superexploitation?}

What is the superexploitation of labour power? How does superexploitation operate? What are its impacts on the working class? This paper aims to answer these questions, showing how the category introduced by Ruy Mauro Marini can be comprehended in accordance with the Marxist theory of value and how it relates to the determination of the value of labour power. The text has been written in order to contribute both to a broader understanding of this category and to present it for those who are not knowledgeable about the dependency debate.

Keywords: Superexploitation; Dependency Theory; Marxist Theory of Value.

JEL B51, J01, F66.

\section{Introdução}

"O fundamento da economia dependente é a superexploração do trabalho" (Marini, 1972, p. 101, tradução própria). Com essa frase, a difusão da teoria da dependência na versão dada por Ruy Mauro Marini tem atingido patamares cada vez mais significativos, desde o seu surgimento há aproximadamente 50 anos. Hoje, a teoria da dependência é um dos mais influentes aportes teóricos de orientação marxista que buscam analisar as relações econômicas no mercado mundial, de forma que quem pretende compreender o funcionamento do modo de produção capitalista em escala global não se pode dar ao luxo de desconhecê-la. E para conhecê-la, tendo em vista a afirmação que abre esse texto - de autoria daquele que atualmente é tido como o maior expoente desse campo teórico -, é preciso entender o que é a superexploração do trabalho.

Segundo Marini (1972, p. 42), a superexploração do trabalho corresponde a uma situação na qual os salários pagos aos trabalhadores são inferiores ao valor da força de trabalho,

\footnotetext{
* Artigo recebido em 10 de julho de 2017 e aprovado em 10 de março de 2018.

${ }^{* *}$ Professor do Departamento de Economia da Universidade Federal do Espírito Santo (UFES), Vitória, ES, Brasil. E-mail: rodrigo.franklin@ufes.br.
} 
impedindo que essa classe se reproduza em suas condições normais. Embora possamos afirmar que Ruy Mauro Marini foi o primeiro autor a utilizar a "superexploração do trabalho" em um sentido distinto do "coloquial", tratando-a como uma categoria com significado próprio dentro do campo teórico marxista, a origem exata da expressão permanece desconhecida.

As primeiras ocorrências do termo "superexploração" aplicado para tratar da situação de trabalhadores submetidos ao trabalho assalariado remontam à primeira metade do século $\mathrm{XX}$, tendo seu uso amplamente difundido na América Latina antes de receber o tratamento dado por Marini. Nesse período, essa expressão - utilizada sempre como sinônimo de "exploração maior que o normal" - foi empregada por alguns autores de influência marxista tanto para abordar a situação de grupos de trabalhadores marginalizados dentro dos países capitalistas avançados (negros, mulheres e jovens), quanto para versar sobre a elevada exploração da classe trabalhadora da periferia submetida ao capital dos países imperialistas ${ }^{1}$.

Nos escritos de Marini, a expressão "superexplotación" aparece pela primeira vez em 1967, no artigo "Subdesenvolvimento e revolução na América Latina", quando, ao versar sobre a transferência de mais-valor que prejudica o capital dos países periféricos em detrimento dos países imperialistas, o autor afirma:

As classes dominantes locais tratam de ressarcir-se dessa perda aumentando o valor absoluto do mais-valor criado pelos trabalhadores agrícolas ou mineiros, ou seja, submetendo-os a um processo de superexploração. A superexploração do trabalho constitui, assim, o princípio fundamental da economia subdesenvolvida, com tudo o que implica em termos de baixos salários, falta de oportunidades de emprego, analfabetismo, subnutrição e repressão policial (Marini, 1967, p. 91, tradução própria).

Nesse primeiro momento do pensamento de Marini, a superexploração representaria uma exploração mais elevada - carregando, portanto, o mesmo sentido "coloquial" presente em autores precedentes - que se dá por meio da ampliação absoluta do mais-valor (mais-valor absoluto).

Entretanto, com a publicação do livro "Subdesenvolvimento e revolução" em 1969, a superexploração passa a ser caracterizada por Marini não como uma "maior exploração", mas como o pagamento de salários inferiores ao valor da força de trabalho. Nessa obra, o autor afirma que a acumulação na periferia se fundamenta na produção de mais-valor absoluto, que

(1) Para citar alguns dos exemplos mais relevantes: em 1934, a Liga Comunista da França (sob a influência de Leon Trotsky) utilizou o termo "surexploitation" para tratar da diferença salarial que prejudicava mulheres, jovens, imigrantes e colonos (Communist League of France, 1934, p. 28); a expressão "superexploitation" aparece na obra do marxista estadunidense Victor Perlo (1951) para qualificar tanto a situação do negro nos Estados Unidos quanto para falar da superexploração nas colônias norteamericanas; em 1959, o guatemalteco Jaime Diaz Rozzotto utilizou a palavra "superexplotación" em sua tese de doutorado de filosofia na Universidade Autônoma do México (UNAM), para denunciar os baixos salários ao qual o capital monopolista norteamericano submetia a classe trabalhadora da Guatemala (Rozzotto, 1958); "superexplotación" aparece também na obra do cientista político espanhol Victor Alba, "Los subamericanos", na qual caracteriza a superexploração como "[...] uma exploração superior à que em uma sociedade capitalista industrializada se pode considerar como normal e que não causa nem miséria econômica, nem isolamento cultural, nem penalidades físicas [...]" e a utiliza para ressaltar a condição infra-humana de grande parte do campesinato e do proletariado latino-americano (Alba, 1964, p. 308, tradução própria). 
se dá tanto pela ampliação das jornadas de trabalho como pela "[...] ruptura da relação entre a remuneração do trabalho e seu valor real, ou seja, entre o que se considera como tempo de trabalho necessário e as necessidades de subsistência efetivamente apresentadas pelo trabalhador [...]" (Marini, 1969, p. 115, tradução própria). A superexploração é apresentada, assim, como "[...] um caso anômalo de mais-valor absoluto" a despeito de parecer ser maisvalor relativo (Marini, 1969, p. 115, tradução própria), um caso em que "[...] a força de trabalho se remunera a um preço inferior ao seu valor real [...]" (Marini, 1969, p. 116, tradução própria).

Com a publicação, em 1972, de "Dialética da dependência", Marini desvincula a categoria da "superexploração" da de mais-valor absoluto², apresentando-a como uma maior exploração da força física do trabalhador que resulta no pagamento de salários inferiores ao valor da força de trabalho. Podemos dizer que nessa obra a "superexploração" alcança sua forma mais acabada, tendo os textos posteriores de Marini apenas contribuído para esclarecer e aprofundar o significado apresentado ali.

Em "Dialética da dependência", o autor indica três mecanismos que seriam responsáveis por essa divergência entre salários e valor da força de trabalho: extensão da jornada de trabalho; ampliação da intensidade do trabalho; e redução do consumo dos trabalhadores como consequência da redução do nível dos salários. Marini explica:

[...] a característica essencial é dada pelo fato de que se nega ao trabalhador as condições necessárias para repor o desgaste de sua força de trabalho: nos dois primeiros casos, porque o obriga a um dispêndio de força de trabalho superior ao que deveria proporcionar normalmente, provocando-se, assim, seu esgotamento prematuro; no último, porque se retira dele inclusive a possibilidade de consumir o estritamente indispensável para conservar sua força de trabalho no estado normal [...] (Marini, 1972, p. 41-42, tradução própria).

Há duas razões fundamentais para que a categoria da superexploração desfrute de um status significativo na teoria de Marini: primeiro, por se tratar de uma forma de exploração mais perversa para o trabalhador do que a ampliação do mais-valor por meio do aumento de produtividade, resultando na "[...] redução progressiva da vida útil do trabalhador, assim como nos transtornos psicofísicos provocados pelo excesso de fadiga [...]" (Marini, 1972, p. 97, tradução própria); segundo, porque essa forma de exploração tende a obstaculizar a transformação da economia dependente de um modo de produção pautado no mais-valor absoluto para um voltado para o mais-valor relativo (Marini, 1972, p. 100) ${ }^{3}$.

Nos anos que se seguiram à publicação de "Dialética da dependência", a categoria da "superexploração" teve sua relevância reconhecida por uma ampla gama dos autores que

(2) Era muito comum que os críticos de "Dialética da Dependência" confundissem a superexploração com o mais-valor absoluto (Cardoso; Serra, 1978). Talvez, esse equívoco possa ter sido influenciado pelos primeiros tratamentos dados pelo autor ao termo.

(3) Sobre a "tese do bloqueio", cf. Katz $(2008,2011)$. 
participavam do debate sobre a teoria da dependência, tanto por se tornar alvo de críticas ${ }^{4}$ quanto por ser incorporada nas mais diversas elaborações ${ }^{5}$. Atualmente, o uso das expressões "superexploração do trabalho" ou "superexploração da força de trabalho"6 encontra-se tão difundido que devemos reconhecer se tratar de uma expressão consolidada no pensamento marxista. Contudo, é preciso observar duas questões.

Em primeiro lugar, uma ampla gama de autores tem usado a "superexploração" em seu sentido coloquial, e não como uma categoria marxista propriamente dita. Esses são os casos daqueles que a utilizam como sinônimo de "maior exploração" - para tratar tanto de uma significativa ampliação relativa ou absoluta do mais-valor em um dado momento, quanto de grupos de trabalhadores que são mais explorados que a média da sociedade ${ }^{7}-$, ou como sinônimo de "maior desgaste físico do trabalhador". Tal uso coloquial não implica em um equívoco teórico, mas apenas reflete o fato de que sua utilização não carrega o sentido elaborado por Marini.

Em segundo lugar, ainda há significantes debates, dentre aqueles que buscam utilizar o termo de acordo com a acepção de Marini, sobre o real sentido dessa categoria, sua validade e relevância. Uma vez que esse autor não deixou clara a forma como sua categoria da "superexploração" se articula com a teoria do valor de Marx e, sobretudo, com a determinação do valor da força de trabalho, é natural que surjam dúvidas e interpretações divergentes. Dentre as controvérsias mais relevantes, podemos citar aquela que questiona se a superexploração consistiria em outro tipo de mais-valor, complementar àquele descrito por Marx em " $\mathrm{O}$ Capital" ${ }^{9}$, ou se seria uma forma específica de se elevar a taxa de exploração ${ }^{10}$.

Assim, com o intuito não só de contribuir para uma compreensão mais ampla dessa categoria, mas também de apresentá-la para aqueles não são conhecedores do debate da dependência, o presente artigo busca expor ao leitor o significado teórico da categoria

(4) Cf. Cueva (1979) e Cardoso e Serra (1978).

(5) Cf. Bambirra (1974, 1978), Santos (1978), entre outros.

(6) Cf. Carcanholo (2013) sobre o debate quanto à adequação do uso "superexploração da força de trabalho" ou "superexploração do trabalho".

(7) Como seria notadamente o caso de alguns grupos étnicos, das mulheres e do trabalho infantil, ou ainda em alguns ramos específicos do mercado de trabalho nos quais se observam uma precarização do trabalho mais intensa do que a média da sociedade (e.g., cortadores de cana). Muitos autores que utilizam o termo "superexploração" para abordar essas situações acreditam que o aplicam no sentido dado por Marini. Contudo, como veremos adiante, tal procedimento consiste em um uso incorreto, a despeito de se tratar de um fenômeno relevante e que mereça a atenção de teóricos marxistas.

(8) Restringindo-se apenas ao desgaste físico, Smith $(2000,2006)$ deixa claro que uma elevada superexploração é compatível com uma baixa taxa de exploração em termos marxistas. Ainda há aqueles que, como Ricardo Antunes (1995, 2004, 2015), utilizam a expressão "superexploração" nos dois sentidos da acepção coloquial.

(9) Como seria o caso, por exemplo, de Osorio (2009, 2013), que afirma que os trabalhadores dos países dependentes seriam duplamente explorados: primeiro, sendo expropriados de uma parcela de sua jornada de trabalho (mais-valor); segundo, sendo expropriados de uma parcela de seu salário (superexploração).

(10) Tal como defende Carcanholo (2013, p. 77), que afirma: "a teoria marxista da dependência entende a superexploração, no sentido de formas ou mecanismos de elevação da taxa de mais-valia, como o conjunto das situações que permitem a elevação do grau de exploração da força de trabalho mediante a redução dos salários para patamar inferior ao valor da força de trabalho $[\ldots]$ ". 
"superexploração" de Ruy Mauro Marini, evidenciando o modo como ela pode ser compreendida dentro da perspectiva marxista. Nossa análise restringe-se aos aspectos teóricoabstratos da categoria, de modo que nos absteremos de observar suas implicações e expressões histórico-concretas.

Tendo em vista que muitos dos problemas que permeiam o atual debate da dependência em torno da categoria "superexploração" estão relacionados com imprecisões de alguns conceitos básicos do marxismo, entendemos por necessário iniciar nossa explanação analisando elementos fundamentais relacionados com o significado de valor, grandeza de valor, valor de troca e sua relação com os preços das mercadorias. Apenas após esclarecermos as possibilidades de distanciamento entre valores e preços de todas as mercadorias, poderemos analisar os desvios entre salários e o valor dessa mercadoria peculiar que é a força de trabalho.

\section{Divergência entre preços e valores}

Elemento central da teoria econômica marxista, o valor consiste em uma forma de relação social na qual os indivíduos se socializam por meio da troca dos produtos de seus trabalhos. O valor, propriedade desses produtos, possui uma dimensão qualitativa e outra quantitativa. Como qualidade, ele evidencia que uma mercadoria é fruto de trabalho humano abstrato. O adjetivo "abstrato" deixa claro que não nos interessa a forma concreta do trabalho individual que resulta no valor de uso, mas a forma social, ou seja, o fato desse trabalho constituir atividade humana que se reconhece como produtora de valor.

Como quantidade, o valor é mensurado pelo quantum de trabalho dispendido, mas um quantum no qual também se faz presente o caráter social. A grandeza do valor consiste no tempo de trabalho socialmente necessário para a produção de uma mercadoria, ou seja, tempo que a sociedade como um todo dispende, em média, na produção de valores de uso de uma mesma qualidade. Como expressão concreta do desenvolvimento das forças produtivas da sociedade, a grandeza de valor não é representação da capacidade máxima ou ideal da produtividade do trabalho, mas a média real do tempo de trabalho atualmente dispendido por todos os produtores individuais que lançam determinado produto em um determinado mercado ${ }^{11}$. Desse modo, podemos representar o tempo de trabalho socialmente necessário $($ TTSN) para a produção de uma mercadoria " $x$ " conforme a equação que segue:

$$
\operatorname{TTSN}_{(\text {mercadoria } x)}=\frac{\sum T_{i}}{\sum Q_{i}}
$$

Onde $T_{i}$ é o tempo de trabalho dispendido por cada trabalhador individual ( $i$ ) na produção de valores de uso de um mesmo tipo $(x)$ que são lançados no mercado ${ }^{12}$; e $Q_{i}$ é a quantidade de mercadorias de um mesmo tipo $(x)$ que cada trabalhador individual $(i)$ lança no mercado.

(11) Isso evidencia que o valor possui uma determinação que se relaciona tanto com o âmbito da produção quanto com o da circulação. Afinal, aqueles produtores que não lançam seus produtos no mercado - ou seja, que não transformam esses valores de uso em mercadorias - não contribuem para a formação do valor social.

(12) Esse tempo de trabalho inclui, é claro, o tempo de trabalho socialmente necessário para a fabricação dos meios de produção consumidos no processo de produção da mercadoria $x$. 
Sempre haverá um grupo de produtores individuais cuja produtividade estará acima da média da sociedade, do mesmo modo que haverá um grupo abaixo da mesma. Mas, independentemente de sua situação individual, os produtores trocam suas mercadorias como se estas contivessem o tempo de trabalho médio. A diferença entre o trabalho individual dispendido na produção de uma mercadoria e o trabalho socialmente necessário faz com que os trabalhadores mais produtivos 13 "absorvam" parcela do trabalho dos menos produtivos.

A grandeza de valor se expressa como valor de troca, ou seja, como proporção em que as mercadorias se intercambiam. O que aparece na troca, portanto, não é o tempo de trabalho socialmente necessário para a produção de uma mercadoria, mas uma quantidade de outra mercadoria que possui a mesma grandeza de trabalho social. A forma preço de uma mercadoria " $x$ " é a expressão do valor de troca dada em termos de um equivalente universal:

$$
\text { Preço } o_{(\text {mercadoria } x)}=\frac{\operatorname{TTSN}_{(\text {mercadoria } x)}}{\operatorname{TTSN}_{(\text {equivalente universal })}}
$$

$\mathrm{Na}$ troca, o vendedor transfere a propriedade de sua mercadoria ao comprador, recebendo deste o montante de equivalente universal expresso pela equação 2 . Contudo, há situações nas quais a venda é realizada apenas por um período determinado, ou melhor, a mercadoria é apenas alugada por certo tempo, de modo que o comprador obtém o direito de usufruir do valor de uso pelo tempo adquirido sem que a propriedade da mercadoria lhe seja transferida. Nesses casos, o comprador não deve pagar o preço que expressa a grandeza do valor total da mercadoria, mas aquele que represente apenas a magnitude do valor que foi destruído durante a vigência do aluguel. Vejamos como esse aluguel é determinado.

O valor total de uma mercadoria que será alugada é determinado da mesma forma que qualquer outra mercadoria (equação 1), cabendo ressaltar que deve ser considerado como tempo de trabalho socialmente necessário não apenas aquele dispendido na produção da mesma, mas também todo o trabalho de manutenção e reparação que esse bem receberá durante toda sua vida útil (Marx, 1867, p. 281, nota 21). Já o valor do aluguel dessa mercadoria é o resultado da diluição desse valor total por todo o tempo em que a mesma será alugada, ou seja, pelo tempo de vida útil esperado. Em termos diários, por exemplo, considerando $U$ como o número de dias em que uma determinada mercadoria “ $x$ ” pode ser alugada, temos:

$$
\text { Valor diário }{ }_{(\text {mercadoria } x)}=\frac{\operatorname{TTSN}_{(\text {mercadoria } x)}}{U}
$$

Se um valor de uso é completamente consumido em 1.000 dias - supondo-se que ele receba a devida manutenção e reparação -, o valor diário de seu aluguel será $\frac{1}{1.000}$ de seu valor total. O preço de seu aluguel diário será a expressão desse valor em termos de equivalente universal:

$$
\text { Preço diário }_{(\text {mercadoria } x)}=\frac{\text { Valor diário }_{(\text {mercadoria } x)}}{\operatorname{TTSN}_{(\text {equivalente universal })}}
$$

(13) Ou seja, aqueles que produzem uma quantidade maior de valor de uso por tempo de trabalho do que a média da sociedade. 
Os preços que atendem às igualdades expressas pelas equações 2 e 3 não são os preços individuais pelos quais cada mercadoria é vendida ou alugada, mas seus preços médios, ou seja, a média pela qual a mercadoria, ao longo de um período de tempo, é transacionada por uma quantidade de equivalente universal. $O$ preço individual de uma mercadoria pode divergir de seu valor tanto em um dado momento quanto ao longo de um período de tempo sem que o preço médio seja distinto do valor. Vejamos essas duas situações.

Para um dado momento do tempo, chamamos o preço que regula a relação de troca de uma mercadoria de "preço de mercado". Como veremos, esse preço de mercado pode se distanciar do valor de troca da mercadoria na medida em que sofre influência das forças da oferta e da demanda. No entanto, mesmo supondo que o preço de mercado seja equivalente ao valor de troca de uma mercadoria (i.e., que atenda à igualdade expressa pela equação 2 ou 3), devemos observar que sempre haverá transações realizadas tanto com preço individual acima quanto abaixo desse preço de mercado. Nesse sentido, pode-se dizer que aquele que vende uma mercadoria com um preço individual acima do preço de mercado, se apropria de parcela do valor cedida por aquele que a vende a preço inferior. Uma vez que o preço de mercado é a média dos preços das mercadorias vendidas, esses desvios se compensam necessariamente.

É interessante notar, contudo, que pode ocorrer do montante de mercadorias que se vendem abaixo do preço de mercado ser maior do que as que se vendem acima - no caso em que dizemos que a distribuição dos preços é assimétrica -, e mesmo assim a média dos preços (i.e., preço de mercado) continua a representar o valor. Ilustramos no Gráfico 1 duas possibilidades de distribuições assimétricas dos preços em um dado momento do tempo. $\mathrm{O}$ Gráfico 1(a) apresenta o caso que podemos chamar de típico ou normal, no qual o preço de mercado divide a massa de mercadorias vendidas ao meio. Já no Gráfico 1(b), ilustramos um caso no qual a maioria das mercadorias se vende por um preço individual abaixo da média dos preços - representado pela linha tracejada vertical. O caso oposto é apresentado no Gráfico 1(c), no qual a maior massa de mercadorias apresenta preços individuais acima da média. Podemos dizer que no caso 1(b) as mercadorias estão em sua maioria "subvalorizadas", enquanto que no caso 1(c) elas estão "sobrevalorizadas".

Gráfico 1

Formas de distribuição dos preços

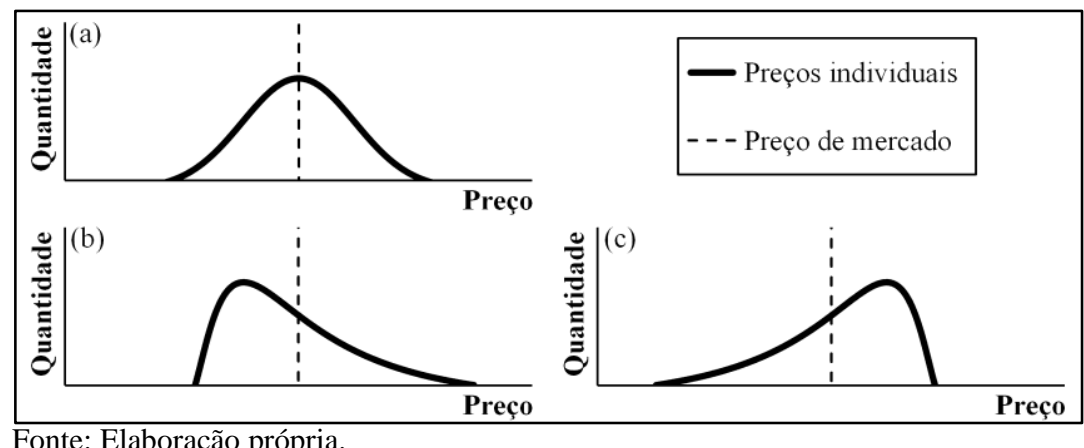


Contudo, para um dado momento, o montante de recursos que alguns consumidores economizam ao comprar as mercadorias subvalorizadas, os outros gastam em excesso com a aquisição da parcela supervalorizada, em qualquer uma das três situações indicadas. Por isso, podemos dizer que o preço médio é o preço social, ou seja, o preço que a sociedade em conjunto paga por unidade da referida mercadoria.

Se ignorarmos todos os fatores perturbadores do processo de formação dos $\operatorname{preços~}^{14}$, teremos como resultado um formato da distribuição cuja determinação repousa sobre causas fortuitas. Independente se a forma dessa distribuição aloca tal ou qual parcela a preços superiores ou inferiores, o fato é que aqueles produtores que vendem mercadorias abaixo do preço médio - e que recebem, portanto, remuneração inferior à média do setor - desejarão alterar sua posição, seja transferindo sua capacidade produtiva para outro setor, seja tentando ampliar os preços de suas mercadorias.

Ao longo de um período de tempo, o resultado desse movimento é uma alteração não só na forma com que os preços se distribuem, mas também no próprio preço de mercado pelo qual as mercadorias se vendem, levando-o a se distanciar do valor. Assim, o preço de mercado é grandeza sempre flutuante, conforme variem a oferta e a demanda da referida mercadoria. Todavia, enquanto se mantiver constante a relação entre o tempo de trabalho socialmente necessário para a produção da referida mercadoria e do equivalente universal, os preços de mercado gravitarão continuamente em torno de um mesmo ponto - do valor de troca da mercadoria -, tal como expresso pelo Gráfico 2. Nos momentos em que o preço de mercado supera o valor de troca, há uma espécie de ganho extra para os vendedores. Entretanto, esse ganho extra é totalmente compensando quando os produtores vendem suas mercadorias por um preço de mercado abaixo do valor de troca na fase seguinte do ciclo de preços.

Gráfico 2

Preços de mercado variáveis com valor de troca constante

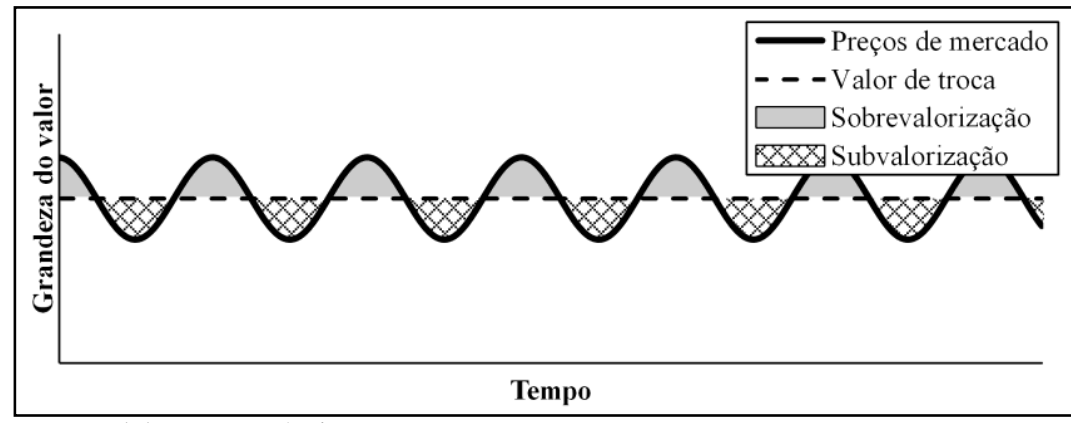

Fonte: Elaboração própria.

O que garante que os preços mantenham-se oscilando em torno do valor de troca são os próprios mecanismos da concorrência. Caso os preços de uma mercadoria se elevem de

(14) Tais como poder de monopólio, distribuição geográfica, etc. 
forma contínua acima do valor de troca, isso atrairá para esse setor outros produtores desejosos em aumentar o retorno sobre seu trabalho, causando uma ampliação da oferta com concomitante redução do nível de preços. Se, ao contrário, os preços de um tipo de mercadoria permanecerem inferiores ao seu valor por um período significativo de tempo, os produtores se sentirão forçados a abandonar o mercado, direcionando-se para setores mais rentáveis e reduzindo a oferta da referida mercadoria e elevando, consequentemente, seu preço.

$\mathrm{Ou}$ seja, a divergência persistente entre preços e valor de uma mercadoria qualquer enseja uma dinâmica econômica que acaba por reestabelecer a igualdade entre essas variáveis por meio da alteração do patamar dos preços, enquanto seu valor permanece o mesmo.

Ademais, ainda é preciso lembrar que o valor de troca também pode sofrer alterações tanto devido à variação da grandeza do valor do equivalente universal quanto à modificação no tempo de trabalho socialmente necessário para a produção da mercadoria resultante do desenvolvimento das forças produtivas da sociedade. O Gráfico 3 ilustra alguns exemplos de como a alteração do valor de troca pode mudar o centro de gravitação dos preços de mercado.

Gráfico 3

Preços de mercado e valor de troca variáveis

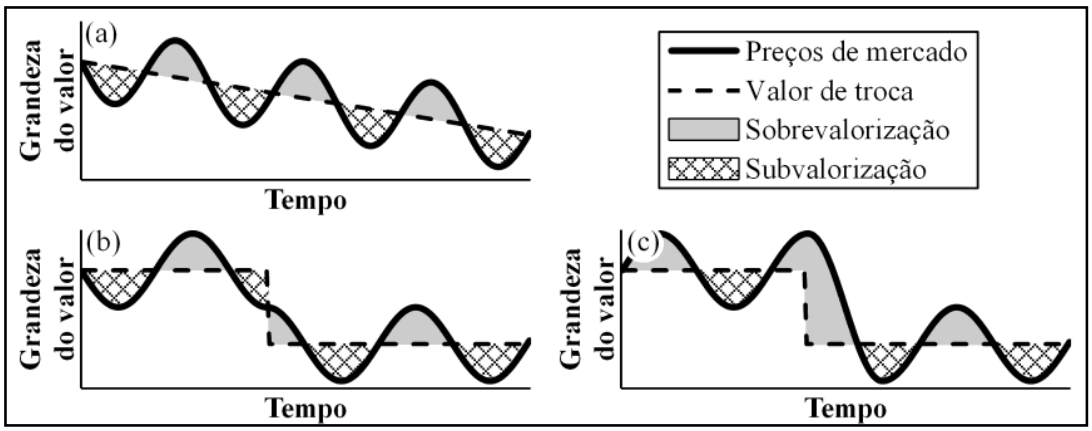

Fonte: Elaboração própria.

É interessante observar que, dependendo de quão abrupta é a alteração no valor de troca, do momento do ciclo em que os preços se encontram e de outros elementos tais como a mobilidade dos fatores de produção, é possível que haja um excedente de mercadorias vendidas a preços sobrevalorizados/subvalorizados. Desse modo, os produtores poderiam se apropriar de um ganho adicional por um período limitado de tempo, quando as condições se mostrarem favoráveis.

Podemos concluir que a existência de preços de mercado divergentes dos valores das mercadorias é condição necessária para a existência do próprio valor, mas sua significância é reduzida na medida em que as variações se compensam mutuamente, exceto em condições excepcionais e por um curto período de tempo. Com isso, resulta como corolário da teoria marxista que os preços médios coincidem com o valor de troca das mercadorias, ou seja, com 
a relação entre o tempo de trabalho socialmente necessário para sua produção e para a produção do equivalente universal ${ }^{15}$.

\section{Divergência entre salários e valor da força de trabalho}

Consideremos, agora, as possibilidades de distinção entre os preços e o valor da mercadoria peculiar que é a força de trabalho, iniciando pela compreensão de como se determinam seu valor e seu valor de troca.

Conforme afirma Marx (1867, p. 245):

$\mathrm{O}$ valor da força de trabalho, como o de todas as outras mercadorias, é determinado pelo tempo de trabalho necessário para a produção - e, consequentemente, também para a reprodução - desse artigo específico. Como valor, a força de trabalho representa apenas uma quantidade determinada do trabalho social médio nela objetivado [...].

Do mesmo modo que ocorre com todas as mercadorias, a grandeza do valor da força de trabalho consiste no tempo que a sociedade como um todo dispende, em média, na produção da força de trabalho de uma mesma qualidade ${ }^{16}$. Como expressão concreta do desenvolvimento das forças produtivas da sociedade, o valor da força de trabalho não representa nem o mínimo necessário e nem a reprodução ideal do trabalhador, mas a média real do tempo de trabalho atualmente dispendido na produção e reprodução de todos os trabalhadores capazes de realizar um trabalho de mesmo grau de complexidade. Com isso, podemos representar o tempo de trabalho socialmente necessário para a produção da força de trabalho de grau de complexidade " $x$ ” conforme a equação que segue:

$$
\operatorname{TTSN}_{(\text {força de trabalho } x)}=\frac{\sum T_{i}}{Q}
$$

Onde $T_{i}$ é o tempo de trabalho dispendido, para o caso de cada trabalhador individual ( $i$ ), na produção de sua força de trabalho de grau de complexidade " $x$ ”; e $Q$ é a quantidade de trabalhadores que ofertam no mercado essa força de trabalho com grau de complexidade " $x$ ".

(15) Ao menos, isso é o que pode ser dito de uma sociedade livre de circunstâncias perturbadoras, tal como ocorreria naquelas formadas por produtores individuais proprietários de seus meios de produção. Todavia, o próprio fundamento do modo de produção capitalista - i.e., o monopólio dos meios de produção pela classe capitalista, de um lado, e a existência de uma classe de trabalhadores duplamente livres, de outro - cria circunstâncias secundárias que permitirão que os preços sejam mantidos em patamares distintos dos valores das mercadorias por um longo período de tempo. Esse é o caso, por exemplo, do processo de equalização das taxas de lucro dos diversos capitais, responsável pela transformação dos valores em preços de produção - que leva Marx a afirmar que quanto mais se desenvolve o modo de produção capitalista, mais os preços passam a gravitar em torno dos preços de produção, e não dos valores das mercadorias (Marx, 1894, p. 211). A despeito disso, o que se disse aqui sobre a divergência entre preços de mercado e valores aplica-se também à divergência entre preços de mercado e preços de produção.

(16) Assim como as demais mercadorias se distinguem conforme a qualidade de seus valores de uso, diferentes forças de trabalho se distinguem conforme a complexidade do trabalho que podem realizar - não pelo fato do trabalho complexo valer como o simples multiplicado (Marx, 1867, p. 122), mas pelo fato de ser necessário maior dispêndio de esforço humano para produzir uma força de trabalho com capacidade complexa. Como consequência, o valor da força de trabalho deve ser calculado para cada grau de complexidade, de modo que não deve ser considerado injusto, dada a lei que rege a troca mercantil, que o valor de uma força de trabalho mais simples (e.g., cortadores de cana) seja inferior ao valor de uma força de trabalho mais complexa (e.g. operário fabril). 
A força de trabalho é um tipo de mercadoria que não se vende por completo em apenas uma transação, mas se aluga repetidamente por períodos definidos. A determinação do valor de seu aluguel ocorre do mesmo modo que o de todas as mercadorias transacionadas nessa mesma forma. Vejamos.

O valor total da força de trabalho leva em consideração, para o cálculo da média social, o tempo de trabalho dispendido por cada trabalhador individual no processo produção e reprodução de sua mercadoria por durante toda sua vida. Assim, o tempo $T_{i}$ da equação 4 pode ser compreendido como a soma de todo o trabalho dispendido em três etapas distintas.

A primeira etapa consiste na produção propriamente dita, ou seja, nos custos incorridos para fazer crescer e se desenvolver o indivíduo com as qualidades e aptidões compatíveis com o grau de complexidade do trabalho em questão. Entram nesse componente tanto a soma da grandeza de valor de todas as mercadorias que cada trabalhador consome até atingir a idade apta ao trabalho quanto os custos de aprendizagem necessários para dotá-lo dos conhecimentos e habilidades adequados ao seu grau de complexidade ${ }^{17}$.

Devemos ressaltar que esses custos de produção são determinados não conforme as condições de criação da força de trabalho que atualmente se encontra no mercado, mas de acordo com as condições em que a próxima geração de trabalhadores está sendo atualmente criada, ou seja, o que se paga a título de custo de produção para a geração atual de trabalhadores se gasta na produção da próxima geração. Como indica Marx:

[...] A quantidade dos meios de subsistência necessários à produção da força de trabalho inclui, portanto, os meios de subsistência dos substitutos dos trabalhadores, isto é, de seus filhos, de modo que essa peculiar raça de possuidores de mercadorias possa se perpetuar no mercado (Marx, 1867, p. 246).

Ao levar em consideração não o dispêndio envolvido na produção do trabalhador individual, mas o que este gasta para a produção de seus descendentes, o valor da força de trabalho reflete o estágio atual do desenvolvimento das forças produtivas da sociedade. Afinal, a grandeza de valor atual de uma mercadoria não é resultado do tempo de trabalho socialmente necessário observado durante o período em que ela foi produzida, mas daquele vigente no momento em que a troca é realizada ${ }^{18}$.

A segunda etapa consiste no período de vida útil do trabalhador, durante o qual ele consome diariamente um montante de meios de subsistência para a sua manutenção e reparação. Marx (1867, p. 245-246) argumenta: “[...] se o proprietário da força de trabalho trabalhou hoje, ele tem de poder repetir o mesmo processo amanhã, sob as mesmas condições no que diz respeito a sua saúde e força [...]". Para isso, o trabalhador usufrui de uma cesta de

(17) "[...] os custos dessa educação, que são extremamente pequenos no caso da força de trabalho comum, são incluídos no valor total gasto em sua produção" (Marx, 1867, p. 247).

(18) Ou, nos termos sugeridos por Marx (1894, p. 448): “[...] o valor das mercadorias é determinado não pelo tempo de trabalho que sua produção custou originalmente, mas pelo tempo de trabalho que custa sua reprodução, tempo este que diminui continuamente em consequência do desenvolvimento da força produtiva do trabalho [...]". 
consumo para fazer frente tanto ao desgaste que sofre no processo produtivo quanto à manutenção rotineira de suas aptidões físicas e mentais.

Uma vez que não é possível saber quantos dias cada trabalhador individual irá trabalhar em toda sua vida útil, o cálculo da grandeza do valor total de meios de subsistência que ele deverá consumir ao longo dessa etapa considera o consumo diário atual dessas mercadorias pelo número de dias que correspondem ao tempo esperado de vida útil dos novos ingressantes no mercado de trabalho ${ }^{19}$. Esse período será tanto mais longo quanto mais desenvolvida for a tecnologia, sobretudo à relacionada com a área da saúde, e tanto mais curto quanto menor for o acesso dos trabalhadores aos bens de subsistência ${ }^{20}$ e/ou mais desgastante for o uso de suas capacidades físicas ${ }^{21}$.

A terceira etapa do processo de produção da força de trabalho refere-se aos gastos advindos do processo de descarte dessa mercadoria ${ }^{22}$. Toda mercadoria que necessita de um processo especial para o descarte de seus resíduos deve levar em conta, na determinação da grandeza de seu valor, o trabalho requerido para sua adequada destinação final. Após o fim de sua vida útil, o trabalhador é o único responsável pelo descarte apropriado de sua força de trabalho, mas os meios necessários para isso devem ser garantidos a ele no momento da venda de sua mercadoria. Desse modo, a grandeza do valor da força de trabalho deve conter também o suficiente para a manutenção diária de um indivíduo pelo número esperado de dias que viverá em aposentadoria ${ }^{23}$. Tal nível de consumo deve permitir ao trabalhador médio aposentado alcançar as condições médias de saúde que se observa nesse grupo populacional.

Vale lembrar que em todas essas três etapas há um elemento físico e outro históricosocial $^{24}$. O elemento físico refere-se a todo o consumo necessário para dotar a classe trabalhadora da qualidade média observada pelo período equivalente à expectativa de vida

(19) O tempo esperado de vida útil dos novos ingressantes corresponde ao número de dias de trabalho esperados para aqueles que acabam de ingressar no mercado, supondo-se que as taxas atuais de egressos por faixa etária permaneçam constantes. Ele representa, desse modo, a média hipotética de vida útil compatível com as condições atuais observadas no mercado. O tempo "esperado" de vida útil é um dado mais fidedigno para ser utilizado como medida do que o tempo "médio" de vida útil dos atuais egressos, pois esse último é influenciado pelas taxas de egressos prevalecentes em períodos anteriores, que não refletem o desenvolvimento atual e concreto das forças produtivas.

(20) Que incluem os produtos e serviços das áreas de saúde, saneamento, etc.

(21) Do mesmo modo que o valor da força de trabalho é diferente conforme o grau de complexidade do trabalho que a mesma é capaz de realizar - pois maiores são os custos para gerar e manter um trabalhador com tal proeza - também é distinta a duração de vida de cada classe devido, sobretudo, ao uso que dela se faz. Sobre esse aspecto, Marx (1867, p. 717) observa: "[...] é justamente entre os trabalhadores da grande indústria que nos deparamos com a duração mais curta de vida".

(22) Embora Marx não tenha abordado este aspecto quando tratou da determinação do valor da força de trabalho, decidimos inclui-lo em nossa explanação por desempenhar um papel significativo em um amplo conjunto de economias capitalistas na atualidade.

(23) Cf. nota de rodapé 19 para a diferença entre tempo "esperado" de vida em aposentadoria e tempo "médio" de vida em aposentadoria.

(24) "[...] O valor da força de trabalho é formado por dois elementos, um dos quais puramente físico, o outro de caráter histórico e social" (Marx, 1865, p. 181). 
atual $^{25}$. Consiste, assim, em um limite mínimo para o valor da força de trabalho - mesmo que elástico, pois, como ressalta Marx (1865, p. 181), “[...] uma sucessão rápida de gerações raquíticas e de vida curta manterá abastecido o mercado de trabalho tão bem como uma série de gerações robustas e de vida longa".

Em contraposição, todo o consumo que não influencia as qualidades físicas e mentais da classe trabalhadora compõe o elemento histórico-social. Refere-se nesse quesito à "[...] satisfação de certas necessidades que emanam das condições sociais em que vivem e se criam os homens [...]" (Marx, 1865, p. 182). A despeito de não influenciar a reprodução física da classe trabalhadora, é considerado como parte integrante do tempo de trabalho necessário para a reprodução do trabalhador por ser resultado de necessidade social, estabelecida pelo costume e observado concretamente no caso de cada trabalhador individual.

A partir da soma de todos esses componentes, podemos calcular a grandeza de valor total da força de trabalho. Chamando de $P_{i}$ o tempo de trabalho dispendido por cada trabalhador na produção da força de trabalho de seus descendentes, $M_{i}$ os custos de manutenção e reparação diários atualmente dispendido pelo indivíduo, $\bar{U}$ a duração esperada em dias de sua vida útil, $\bar{D}$ o custo médio diário de descarte dessa mercadoria e $\bar{A}$ o tempo esperado de aposentadoria de um trabalhador em dias, podemos expressar a grandeza total de seu valor conforme a seguinte equação:

$$
\operatorname{TTSN}_{(\text {força de trabalho } x)}=\frac{\sum T_{i}}{Q}=\frac{\left.\sum\left[P_{i}+\left(M_{i} \cdot \bar{U}\right)+(\bar{D} \cdot \bar{A})\right]\right)}{Q}=\bar{P}+(\bar{M} \cdot \bar{U})+(\bar{D} \cdot \bar{A})
$$

Se o trabalhador vendesse sua força de trabalho de uma só vez, deveria obter em troca um montante de equivalente universal que contivesse essa mesma grandeza de valor ${ }^{26}$. Mas ao invés disso, o trabalhador aluga sua força de trabalho para o capitalista por um período determinado conforme o hábito de cada mercado. Se, por exemplo, a aluga em base diária, deve receber em troca apenas a parcela de equivalente universal que corresponde àquele dia de trabalho. Para usar o exemplo de Marx (1867, p. 308), se 30 são os anos de vida útil de um trabalhador, então $30 \times 365=10.950$ é o número de dias que um trabalhador médio pode trabalhar. Assim, para cada dia de trabalho, deve receber $\frac{1}{10.950}$ do valor total de sua força de trabalho. Desse modo, a grandeza diária do valor da força de trabalho (Valor diário) é obtida dividindo-se seu valor total, representado na equação 5, pelo período esperado de sua vida útil, de modo que temos:

$$
\text { Valor diário } \text { (força de trabalho } x)=\frac{\operatorname{TTSN}_{(f \text { orça de trabalho } x)}}{\bar{U}}=\bar{M}+\frac{\bar{P}+(\bar{D} \cdot \bar{A})}{\bar{U}}
$$

(25) Vale ressaltar que esse elemento "físico" também se refere às necessidades mentais do trabalhador.

(26) Embora, como ressalta Marx (1865, p. 159), “[...] se lhe fosse permitido vendê-la sem limitação de tempo, teríamos imediatamente restabelecida a escravatura". 
Já o valor de troca da força de trabalho - isto é, o salário -, em termos diários, é determinado pela relação entre essa grandeza diária e o tempo de trabalho necessário para produzir uma unidade do equivalente universal, de modo similar à equação 3:

$$
\text { Salário diário }=\frac{\text { Valor diário }_{(\text {força de trabalho } x)}}{\operatorname{TTSN}_{(\text {equivalente universal })}}
$$

Uma vez esclarecidos o que é o valor de troca da força de trabalho, vejamos quais são as condições para que a diferenciação entre a remuneração recebida pelo trabalhador e esse valor de troca possa ser chamada de "superexploração".

Em primeiro lugar, é preciso lembrar que o "salário de mercado" é o elemento que regula a compra e venda da força de trabalho em um dado momento do tempo. Mesmo quando o salário de mercado coincide com aquele expresso pela equação 7, sempre haverá trabalhadores recebendo salários individuais maiores e menores do que a média. Mas, o que uns trabalhadores recebem a mais, outros recebem a menos. Cabe observar ainda que a distribuição dos salários pode ser assimétrica, similar aos exemplos apresentados no Gráfico 1. Poderíamos falar, nos casos em que a maior parcela dos trabalhadores recebesse salários inferiores à média - tal como no Gráfico 1(b) -, que predomina uma situação de superexploração. Entretanto, incorreríamos em certa imprecisão no uso do termo, pois quem se apropriaria desse valor residual seriam os trabalhadores "subexplorados", já que a classe capitalista em conjunto pagaria um salário médio equivalente ao valor de troca da força de trabalho para a classe trabalhadora como um todo ${ }^{27}$.

Em segundo lugar, devemos observar que os salários de mercado devem apresentar um comportamento cíclico ligado ao ciclo econômico, de modo que sempre haverá momentos em que poderíamos dizer que os trabalhadores são "superexplorados". Entretanto, essa denominação também não é adequada nessa situação, pois os salários de mercado mais baixos dos períodos de recessão são compensados pelos salários de mercado mais elevados dos momentos de prosperidade. Como podemos observar pela ilustração representada no Gráfico 4, a massa de mais-valor é a mesma tanto se essa for considerada como a diferença entre a magnitude da jornada e a grandeza do valor da foça de trabalho quanto como a diferença entre aquela e a grandeza de valor expressa pelos salários de mercado - pois, nesse segundo caso, os períodos nos quais o capitalista ganha a menos são compensados pelos períodos que obtém um "ganho de superexploração", ou seja, pela parcela adicional de mais-valor que absorve por pagar salários inferiores aos valores da força de trabalho.

(27) É nesse sentido que, se utilizamos a categoria da superexploração de Marini para tratar da exploração mais elevada sofrida por grupos de trabalhadores específicos, devemos admitir que o beneficiário é o restante da classe trabalhadora. Isso implica dizer, por exemplo, que os trabalhadores brancos ("subexplorados") se apropriam de parcela do valor gerado pelos trabalhadores negros, indígenas etc. ("superexplorados"); ou que os trabalhadores se apropriam de parcela do valor gerado pelas trabalhadoras. Afinal, se um grupo de trabalhadores recebe salários inferiores ao médio, o restante é remunerado acima dessa média. Todavia, o uso do termo é correto quando empregado em seu sentido coloquial - ou seja, apenas para afirmar que mulheres, negros etc. são mais explorados do que a média dos trabalhadores que realizam o mesmo grau de complexidade do trabalho. 
Gráfico 4

Comportamento cíclico dos salários de mercado

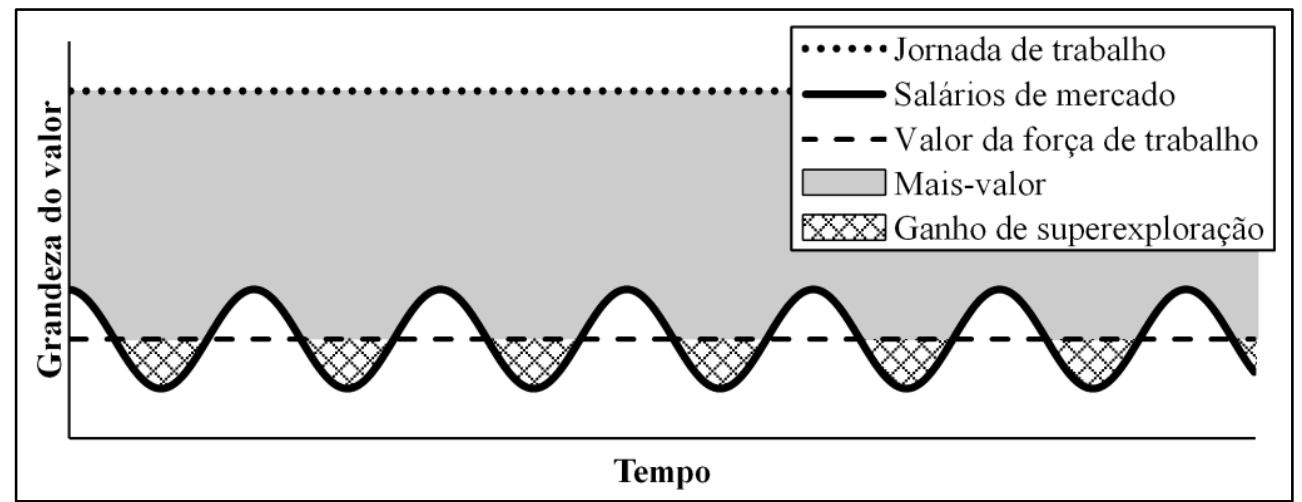

Fonte: Elaboração própria.

Sendo assim, vemos que só faz sentido chamarmos de "superexploração" as situações nas quais o pagamento de salários em um patamar inferior ao valor da força de trabalho não é compensado nem, em um dado momento no tempo, por uma parcela de trabalhadores remunerados com salários superiores ao valor, e nem, ao longo do ciclo econômico, por uma inversão dessa diferença. Vejamos as situações nas quais tal fenômeno seria possível.

Primeiramente, mantendo o pressuposto de que os salários flutuam em torno do valor da força de trabalho ao longo do ciclo econômico, podemos observar a possibilidade da ocorrência de superexploração em situação similar à venda de mercadorias subvalorizadas/sobrevalorizadas representadas no Gráfico 3. Para o caso particular da força de trabalho, ilustramos no Gráfico 5 abaixo que, a depender de quão abrupta é a mudança do valor da força de trabalho ${ }^{28}$ e do momento do ciclo do salário que tal fato ocorre, poderá haver um ganho de superexploração por parte dos capitalistas que não é compensado por um movimento contrário (de "subexploração"). Contudo, a ocorrência de tal fenômeno não parece possuir maior significação teórica por se tratar de um caso fortuito - que, inclusive, antecede uma redução da taxa de exploração.

Uma segunda situação pode ser observada quando abandonamos o pressuposto de que os salários flutuam em torno do valor da força de trabalho. Vimos, quando analisamos os determinantes dos valores e preços das mercadorias, que o abandono do pressuposto de igualdade entre essas variáveis só seria plausível se inseríssemos alguns elementos perturbadores, tal como um poder de monopólio por parte de algum grupo de produtores. No caso da mercadoria força de trabalho, devemos observar que sua existência já repousa sobre o pressuposto de um monopólio: o monopólio da propriedade dos meios de produção pela classe capitalista.

(28) Que poderia derivar da ampliação do tempo de trabalho necessário para a produção de alguma mercadoria que compõe a cesta de consumo dos trabalhadores. 
Gráfico 5

Efeito de variações do valor da força de trabalho nos salários

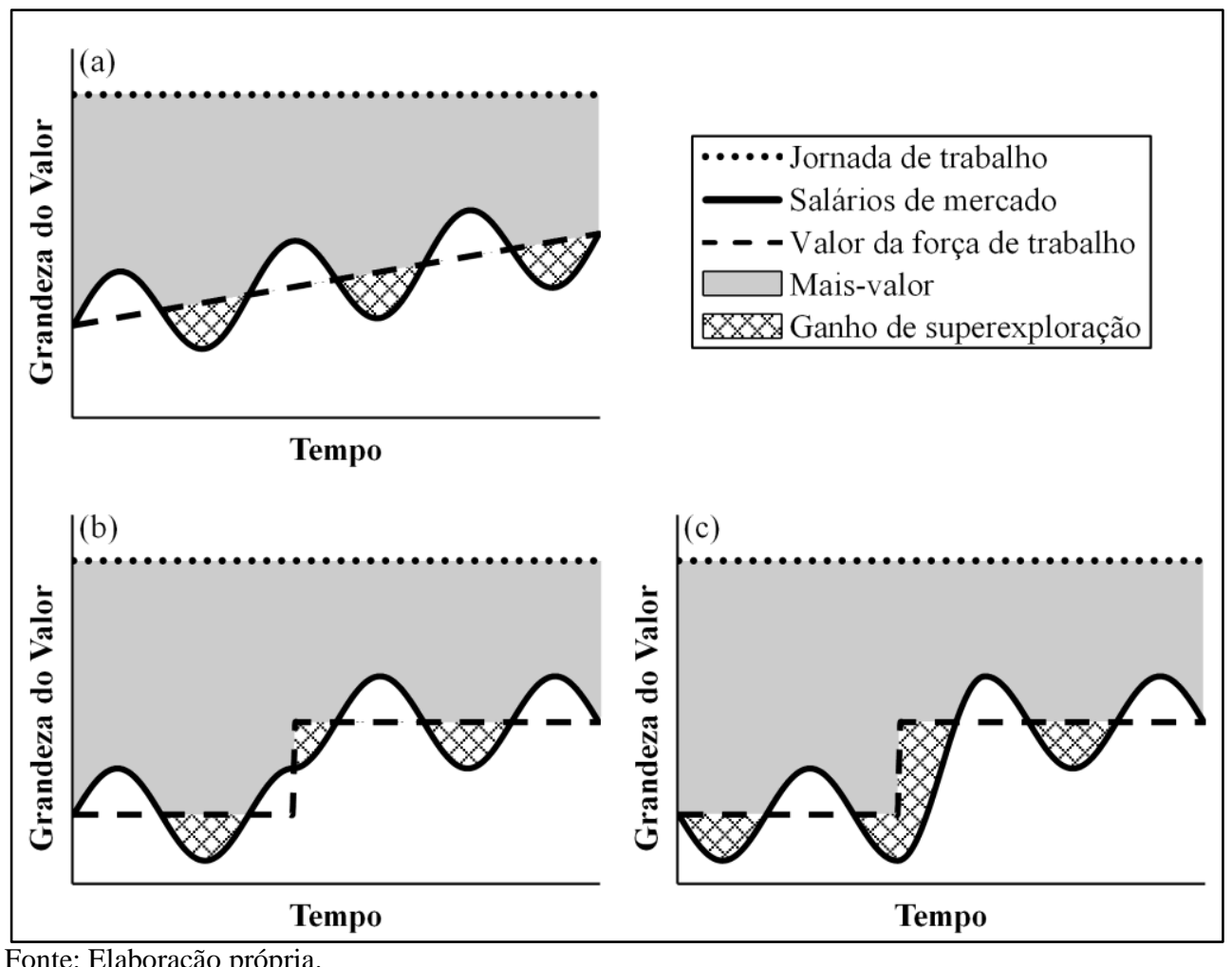

Como os trabalhadores não podem abster-se de vender sua força de trabalho quando os salários se tornam baixos demais, pois não podem garantir seu sustento de outro modo sem o acesso aos meios de produção, uma redução dos salários não enseja uma concomitante redução da oferta de mão de obra - i.e., não gera, por si só, uma tendência contrária capaz de reestabelecer o equilíbrio. Com isso, no caso dessa mercadoria peculiar, a igualdade entre seu preço e seu valor depende da capacidade dos trabalhadores organizados pressionarem a classe capitalista por uma elevação de seus salários, em outras palavras, depende da luta de classes.

Sendo assim, em uma situação na qual a luta de classes pende em desfavor da classe trabalhadora, é possível que os salários médios sejam mantidos "artificialmente" em um patamar insuficiente para adquirir a cesta de consumo diária estabelecida na equação 4. É essa situação, resultante do poder de monopólio que decorre da apropriação privada dos meios de produção pela classe capitalista, que é compatível com aquilo que Marini entende por "superexploração".

Como já indicamos, Marini aponta que a superexploração é resultado de três distintos processos: a redução do consumo do operário além do seu limite normal; o aumento da intensidade do trabalho; e o prolongamento da jornada de trabalho. Vejamos, em cada um 
desses processos, como que o salário se distancia do valor e como que esse distanciamento gera efeitos que o impedem de se manter por longos períodos.

\subsection{Redução do consumo da classe trabalhadora}

A redução forçada do consumo dos trabalhadores consiste em um método de se ampliar a taxa de mais-valor de forma relativa, ou seja, uma alteração no modo como uma extensão constante da jornada de trabalho se reparte em parcela de trabalho necessário e trabalho excedente $^{29}$. Nessa forma, o trabalho não pago se excede para além de seu limite normal, "mediante a invasão usurpatória do domínio do tempo de trabalho necessário" para a reprodução do trabalhador (Marx, 1867, p. 388).

Como já foi indicado, a cesta de consumo dos trabalhadores possui um elemento físico, relacionado com as necessidades básicas de reprodução da força de trabalho, e outro elemento histórico-social, estabelecido pelo costume de cada sociedade. A redução forçada do consumo dos trabalhadores pode atuar de duas formas: primeiro, reduzindo apenas o elemento históricosocial de seu valor - caso em que não produziria nenhum impacto na qualidade média da força de trabalho e na expectativa de vida da classe trabalhadora -; segundo, reduzindo também o que se destina à manutenção física da força de trabalho, levando o salário abaixo de seu limite mínimo - caso em que a classe trabalhadora se atrofia, vegeta e morre precocemente.

Nesses dois casos, é preciso observar uma das peculiaridades da força de trabalho: ao contrário das demais mercadorias, o constante pagamento de salários em desacordo com o valor influencia as próprias condições de reprodução do trabalhador. Quando atua apenas sobre o elemento histórico-social, na medida em que uma redução dos salários médios se mostra persistente, ela transforma o próprio costume e comportamento médio dos trabalhadores. Quando a redução dos salários leva-os abaixo do limite mínimo, as consequências são mais drásticas: uma remuneração insuficiente reduz a capacidade da classe trabalhadora de consumir os produtos necessários para a realização das três etapas de produção da força de trabalho. Vejamos os efeitos gerados em cada uma delas.

No que tange à primeira etapa da produção da força de trabalho, com a redução dos salários se reduzem os gastos relativos à alimentação, educação e formação dos filhos dos trabalhadores atuais. Gera-se, com isso, uma mão de obra de qualidade inferior, constituída de trabalhadores desnutridos e destreinados, que são lançados mais cedo ao mercado para garantirem o próprio sustento.

Todavia, a redução dos salários também afeta a etapa de manutenção da força de trabalho. Como não recebem o suficiente, os trabalhadores não podem adquirir a totalidade dos bens necessários para sua adequada reprodução normal. Assim, a deterioração diária que cada

(29) Conforme descreve Marx (1867, p. 390): “o mais-valor que [...] deriva da redução do tempo de trabalho necessário e da correspondente alteração na proporção entre as duas partes da jornada de trabalho chamo de mais-valor relativo". Ao contrário de Marx, Marini considera a redução do consumo do trabalhador uma forma "análoga" ao mais-valor absoluto, pois não a compreende como uma redução do tempo de trabalho necessário. Cf. Marini (1969, p. 115, 148; 1972, p. 92). 
trabalhador observa colabora para a redução da qualidade média de vida da população, além de gerar impactos significativos na capacidade de trabalho média ${ }^{30}$.

A fase da aposentadoria, última etapa da produção da força de trabalho, se vê três vezes prejudicada. Os anos de vida que um trabalhador mediano espera viver em aposentadoria se reduzem devido às deterioradas condições de saúde e alimentação que observam em sua infância; à incapacidade de repor o desgaste diário durante sua vida útil; e à redução do nível de consumo adequado à vida em aposentadoria.

Com isso, produz-se uma força de trabalho desnutrida, desqualificada e pouco produtiva, composta de trabalhadores acostumados com o pauperismo, com a vida curta e com a penúria em período de aposentadoria. Para se produzir esse tipo de trabalhador, se gasta menos tempo de trabalho. Por isso, à medida que esses pobres diabos, desvios no processo de produção da classe trabalhadora, aumentam em número e passam a constituir o caso padrão a qualidade média da mercadoria que se lança no mercado - o próprio valor da força de trabalho diminui.

Do ponto de vista mercantil, o capitalista de hoje deve pagar aos trabalhadores aquilo que estes atualmente gastam para se reproduzir em tão baixa qualidade, mesmo que esses trabalhadores tenham atingido esse nível devido às reduções pretéritas nos salários. Troca-se equivalente por equivalente, e quem comercializa hoje não deve ser punido pelas fraudes que outros realizaram no passado.

Portanto, ao contrário do que acontece com as demais mercadorias - para as quais uma divergência entre preços e valor gera uma dinâmica econômica que reestabelece o equilíbrio por meio de uma alteração nos seus preços -, as peculiaridades da mercadoria força de trabalho fazem com que uma divergência persistente entre salários e valor enseje uma dinâmica econômica que acaba por reestabelecer a igualdade entre essas variáveis por meio de uma alteração no próprio valor da força de trabalho, enquanto os salários permanecem os mesmos.

Entretanto, como a redução do valor só se concretiza quando a baixa remuneração influencia o costume e as estatísticas dos componentes da força de trabalho, há um período no qual a classe capitalista se apropria "indevidamente" de um mais-valor adicional, isto é, um ganho extra e de caráter temporário. Esse é o excedente da superexploração do trabalho.

O Gráfico 6 ilustra a dinâmica dessa forma de mais-valor relativo, evidenciando o ganho efêmero da superexploração. Nele, representamos o salário médio sem suas variações cíclicas, com o intuito de evidenciar a natureza do fenômeno. Assim, a redução dos salários aparece de forma abrupta e é seguida por uma gradual redução do valor da força de trabalho, até o momento que a igualdade entre salários e valor é restabelecida.

(30) Soma-se a esses efeitos a redução da vida útil esperada, cujas consequências serão analisadas com mais detalhes a seguir. 
Gráfico 6

Ampliação relativa do mais-valor por meio da redução de salários sem variações cíclicas

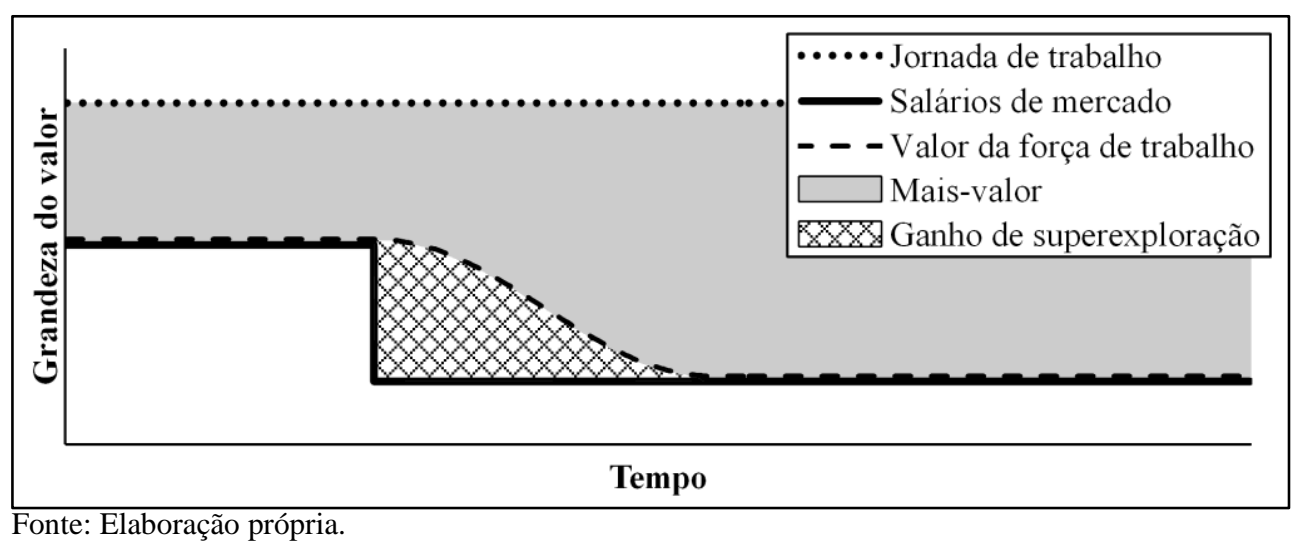

Normalmente, esse processo de redução do salário médio deve ocorrer ao longo dos ciclos econômicos. No Gráfico 7, ilustramos como um mais-valor adicional a título de superexploração é absorvido pelo capitalista nessa situação. Como a redução dos salários antecipa a redução do valor da força de trabalho, há um período de preponderância da superexploração, que se inicia quando os salários passam a apresentar uma tendência decrescente $\left(\mathrm{t}_{1}\right)$ e se estende até o momento em que o valor da força de trabalho se adequa à nova média de remuneração $\left(\mathrm{t}_{2}\right)$.

Gráfico 7

Ampliação relativa do mais-valor por meio da redução de salários no decorrer de variações cíclicas

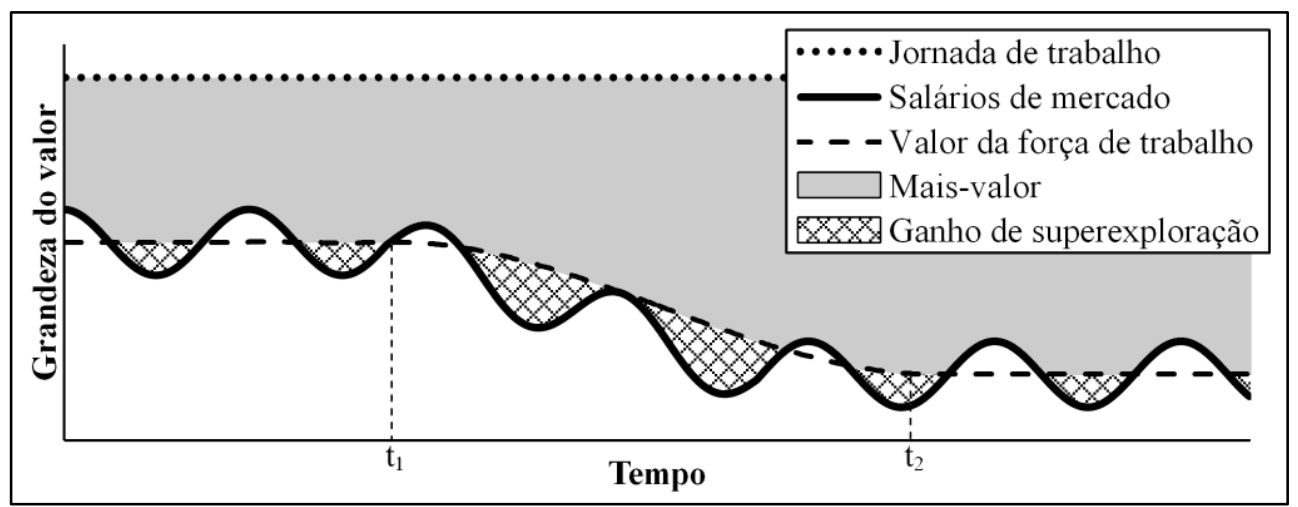

Fonte: Elaboração própria.

Podemos retirar duas conclusões importantes a partir da análise do Gráfico 7. Primeiro, vemos que a classe capitalista absorve um ganho líquido a título de superexploração apenas dentro do período no qual há uma redução do salário médio - de modo que, para receber esse ganho continuamente, é preciso que os salários estejam continuamente em uma trajetória de queda. Em segundo lugar, como resultado do processo que gera a superexploração, há uma 
Rodrigo Straessli Pinto Franklin

ampliação permanente da taxa de exploração após o estabelecimento do novo patamar para o valor da força de trabalho.

\subsection{Ampliação da jornada/intensidade do trabalho}

O prolongamento da jornada de trabalho ou a ampliação de sua intensidade são formas de ampliar a taxa de mais-valor que, em si, não possuem relação direta com o fenômeno da superexploração. Contudo, ambas podem causar o efeito indireto de ampliar o desgaste do trabalhador, elevando o valor da força de trabalho. Vejamos.

Marx (1867, p. 306) afirma: “[...] a jornada de trabalho é [...] determinável, mas é, em verdade, indeterminada", ou seja, apesar da jornada se referir a um número de horas estabelecido, não existe nenhuma lei econômica que nos permite calcular a magnitude desse número. Há, entretanto, limites mínimo e máximo dentro dos quais a jornada deve ser fixada. Como limite máximo, o número de horas trabalhadas por dia deve: reservar um período dentro do qual o ser humano irá descansar e satisfazer suas necessidades físicas ${ }^{31}$; além do tempo para “[...] satisfazer as necessidades intelectuais e sociais, cuja extensão e número são determinados pelo nível geral de cultura de uma dada época [...]" (Marx, 1867, p. 306).

Ao pressionar pelo aumento da jornada, os capitalistas comprimem inicialmente o tempo necessário para fazer frente às necessidades histórico-sociais, processo que não afeta em nada o desgaste da força de trabalho. Entretanto, após eliminarem por completo esse período, podem fazer a jornada de trabalho avançar para além dos limites físicos, comprometendo sua manutenção e encerrando de modo precoce sua vida útil ${ }^{32}$.

Algo similar ocorre com a intensidade do trabalho, que normalmente está em relação inversa com a extensão da jornada de trabalho ${ }^{33}$. Mesmo quando não varia a magnitude da jornada de trabalho, a classe trabalhadora pode ver a intensidade do trabalho ampliada acima do que se considera normal sem observar uma redução de sua vida útil, caso que ocorre quando o maior desgaste da força de trabalho ainda pode ser dissolvido pelo tempo de descanso e pela manutenção corrente da força de trabalho. Entretanto, há um limite a partir do qual a ampliação da intensidade a uma jornada constante implica redução da vida útil do trabalhador, quando o desgaste excessivo de nervos e músculos no processo de trabalho é tão profundo que sua repetição diária impede sua regeneração física e mental.

Existe, portanto, a possibilidade de que, ao ampliar a taxa de mais-valor por meio da extensão da jornada e/ou intensificação do trabalho, a classe capitalista provoque um desgaste

(31) Também deve ser considerado dentro desse período o tempo necessário para restabelecer as condições psíquicas do trabalhador, evitando que a elevação do nível de estresse do mesmo comprometa a qualidade da força de trabalho.

(32) “[...] A produção capitalista, [...] com o prolongamento da jornada de trabalho, [...] produz o esgotamento e a morte prematuros da própria força de trabalho. Ela prolonga o tempo de produção do trabalhador durante certo período mediante o encurtamento de seu tempo de vida" (Marx, 1867, p. 338).

(33) "[...] a eficiência da força de trabalho é inversamente proporcional a seu tempo de operação [...]” (Marx, 1867, p. 482). 
do trabalhador maior do que o observado até então. Esse desgaste pode apresentar três efeitos distintos sobre a grandeza de valor diário da força de trabalho, como se observa pela análise dos componentes da equação 6.

Primeiramente, um consumo mais elevado de bens de subsistência pode ser necessário para que esse desgaste seja completamente revertido, de modo a preservar a qualidade média do trabalhador. Nesse caso, os custos médios de manutenção e reparação diários - a variável $\bar{M}$ da equação 6 - se elevam, juntamente com o valor diário da força de trabalho ${ }^{34}$.

Alternativamente, o maior desgaste - se não for equacionado pelo aumento do consumo de bens de subsistência - pode implicar uma redução da vida útil esperada do trabalhador $(\bar{U})$. Com isso, os custos médios relativos à produção da força de trabalho e ao descarte dessa mercadoria $-\bar{P}+(\bar{D} \cdot \bar{A})$ - deverão ser diluídos em uma quantidade menor de dias, ampliando a grandeza diária do valor que deve ser repassado ao trabalhador.

Devemos observar que a ampliação dos custos de manutenção e a redução da vida útil podem ainda atuar em conjunto em duas situações: quando o desgaste maior tiver seu efeito dividido entre essas duas variáveis; ou então, quando esse desgaste for tão significativo que uma ampliação da cesta de consumo não seja capaz de reverter todos os seus efeitos.

Por fim, no que tange ao período de aposentadoria, o maior desgaste da força de trabalho gera dois efeitos contrários. Primeiro, eleva o custo com o consumo diário de bens de subsistência necessários para que o trabalhador aposentado alcance as condições médias até então vigentes de saúde desse grupo populacional $(\bar{D})$, algo que tem claro efeito de elevar o valor da força de trabalho. Segundo, o próprio tempo esperado de vida em aposentadoria $(\bar{A})$ se reduz devido à morte prematura do trabalhador, o que causa queda no valor da força de trabalho. É provável que a elevação dos demais componentes do valor da força de trabalho supere os efeitos da redução da vida em aposentadoria.

Assim, quando o valor da força de trabalho se eleva como consequência do maior desgaste no processo produtivo, é necessário que esse processo seja acompanhado de uma elevação dos salários médios para que os trabalhadores preservem o mesmo padrão de reprodução até então vigente. Caso essa elevação salarial não se observe, começa a ter efeito o mesmo fenômeno descrito anteriormente, em que salários inferiores geram a redução do valor da força de trabalho. Segue-se, portanto, uma nova ampliação do mais-valor, dessa vez de forma relativa, após a qual ressurge a igualdade entre valores e salários.

Ilustramos no Gráfico 8 os possíveis efeitos de uma ampliação da jornada de trabalho e a ocorrência da superexploração ${ }^{35}$. O Gráfico 8(a) exemplifica uma situação em que a

(34) “[...] se o prolongamento antinatural da [jornada] de trabalho [...] encurta o tempo de vida do trabalhador singular [...], torna-se necessária [...] a inclusão de custos de depreciação maiores na reprodução da força de trabalho, do mesmo modo que a parte do valor a ser diariamente reproduzida de uma máquina é tanto maior quanto mais rapidamente ela se desgaste [...]" (Marx, 1867, p. 338).

(35) Os efeitos para uma intensificação do trabalho seriam similares, motivo pelo qual nos abstemos de entrar em maiores detalhes sobre esse tópico. 
ampliação da jornada ocorre em magnitude que não gera um maior desgaste da força de trabalho, tendo como único resultado a ampliação absoluta do mais-valor.

Efeitos da ampliação da jornada de trabalho

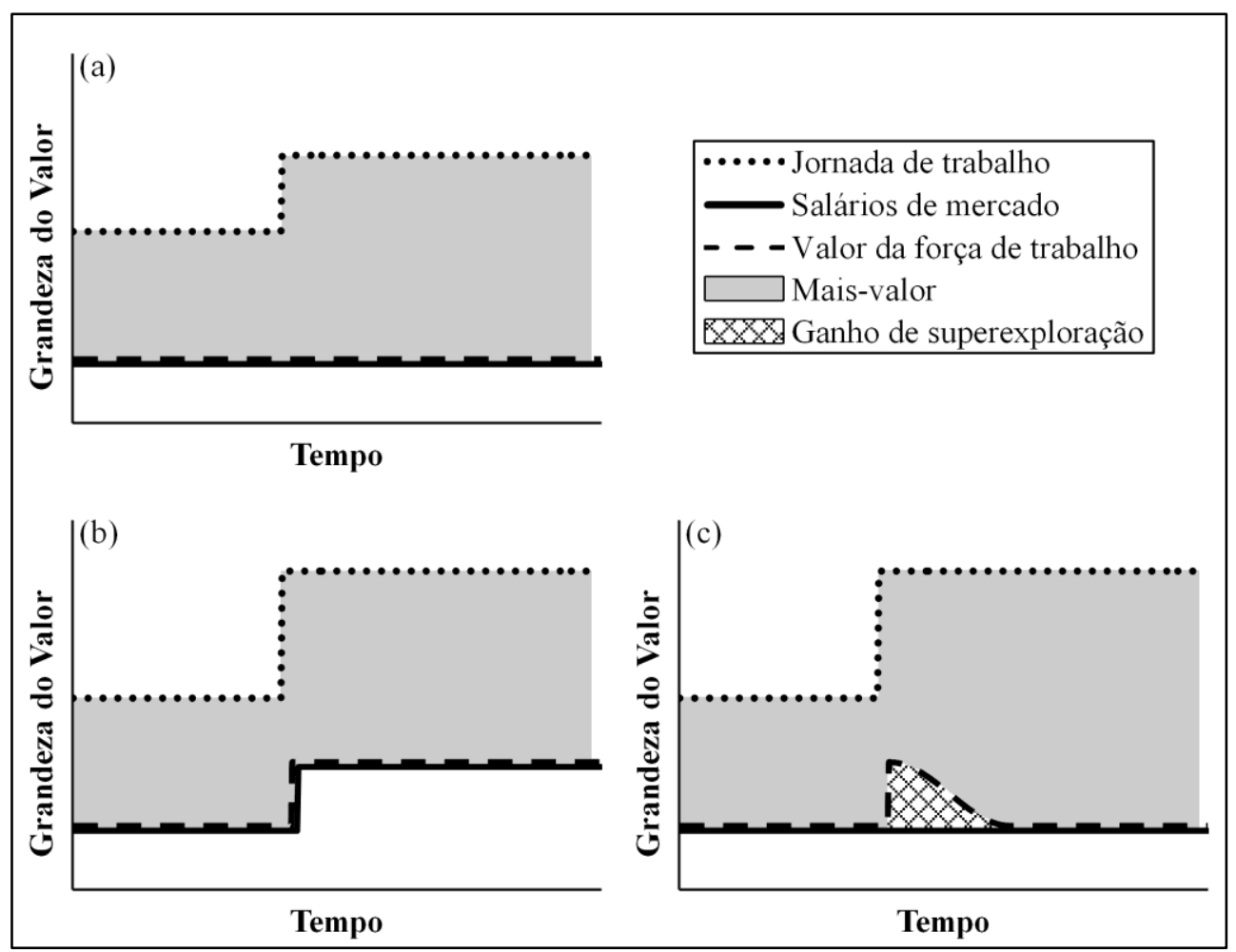

Fonte: Elaboração própria.

Já os Gráficos 8(b) e 8(c) apresentam situações nas quais a ampliação da jornada compromete a reprodução da força de trabalho de modo a determinar o aumento de seu valor. Assim, no caso em que o salário de mercado se eleva para acompanhar o aumento do valor da força de trabalho - Gráfico 8(b) -, há uma ampliação do mais-valor pela via absoluta limitada pela elevação do valor da força de trabalho. Mas se os salários não se elevam, como ocorre no Gráfico 8(c), inicia-se um processo de ampliação relativa do mais-valor ${ }^{36}$, além de um ganho de superexploração que desaparece à medida que os salários insuficientes alteram a qualidade média da força de trabalho.

Como o objetivo do Gráfico 8 é o de evidenciar a natureza do fenômeno, eliminamos os efeitos das variações cíclicas dos salários de mercado e apresentamos uma ampliação brusca

(36) Estamos chamando de mais-valor relativo pelo fato de não estar relacionada diretamente com a ampliação da jornada, mas com uma nova divisão entre trabalho necessário e trabalho não pago após a fixação da nova jornada. 
da jornada de trabalho. Entretanto, no mundo concreto, a dinâmica da ampliação absoluta do mais-valor se dá de uma forma que é ao mesmo tempo mais complexa e mais sutil.

No Gráfico 9 ilustramos como o fenômeno seria observado considerando esses outros dois elementos. Nesse exemplo, o impacto da elevação da jornada no valor da força de trabalho só tem início a partir do momento em que a extensão da jornada ultrapassa o limite máximo determinado pelas necessidades físicas dos trabalhadores, o que ocorre no período $t_{1}$ indicado no Gráfico. O valor da força de trabalho só inicia seu retorno ao nível do salário médio com o fim da ampliação da jornada, e só alcança esse patamar após o tempo necessário para que a não variação dos salários reduza a qualidade de vida média da classe operária.

Gráfico 9

Efeito da ampliação da jornada com salários cíclicos

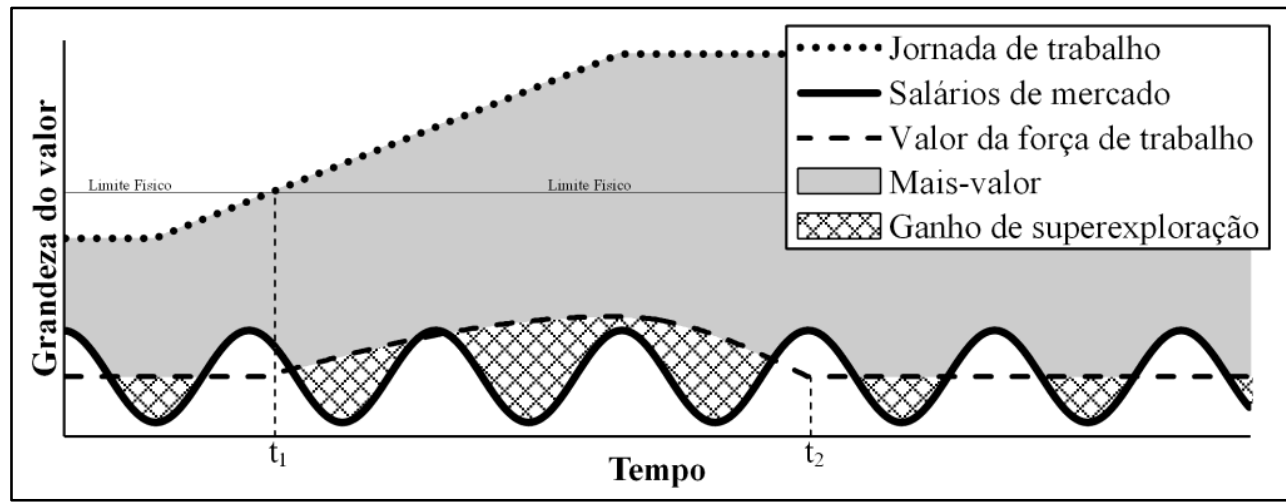

Fonte: Elaboração própria.

$\mathrm{Na}$ análise do Gráfico 9, podemos retirar as mesmas duas conclusões que havíamos observado quando examinamos a redução do salário médio. Em primeiro lugar, vemos que o ganho líquido que a classe capitalista absorve a título de superexploração cessa algum tempo depois do término da trajetória ascendente da jornada de trabalho - de modo que, para receber esse ganho continuamente, é preciso que a jornada eleve-se continuamente. Segundo, como resultado do processo que gera a superexploração, há uma ampliação permanente da taxa de exploração após o estabelecimento do novo patamar para o valor da força de trabalho.

\section{Conclusão}

Tivemos por objetivo, no presente artigo, detalhar o conteúdo teórico da categoria "superexploração" de Ruy Mauro Marini, evidenciando o modo como ela pode ser compreendida de acordo com a teoria do valor de Karl Marx.

Concluímos que a superexploração é o pagamento de salários em um patamar inferior ao valor da força de trabalho que não é compensado nem - em um dado momento - por uma parcela de trabalhadores "subexplorados", e nem - ao longo de um ciclo - por uma inversão 
dessa diferença. Vimos que essa situação é passível de acontecer em duas circunstâncias. A primeira se dá quando uma elevação abrupta do valor da força de trabalho ${ }^{37}$ coincide com a fase descendente do movimento cíclico dos salários. Essa circunstância, todavia, não é merecedora de mais atenção por parecer se tratar de um caso fortuito - que antecede uma redução na taxa de exploração.

Outra circunstância seria aquela na qual a classe capitalista conseguiria manter os salários em patamares inferiores de forma "artificial" por um longo período de tempo. Analisamos como esse fenômeno seria causado pelos três processos descritos por Marini: o primeiro processo consistiria em uma redução persistente do salário real, fazendo-o cair abaixo do montante suficiente para adquirir as mercadorias que compõem a cesta de consumo média até então vigente da classe trabalhadora; os outros dois processos seriam a ampliação da jornada ou da intensidade do trabalho que, em determinadas condições, podem resultar em uma elevação do valor da força de trabalho que, caso não seja acompanhada de uma correspondente elevação dos salários, impediria os trabalhadores de se reproduzirem no mesmo patamar qualitativo.

Vimos também o motivo pelo qual o valor da força de trabalho se reduz quando, como resultado desses três processos, os trabalhadores recebem remunerações inferiores ao necessário para que se reproduzam no nível vigente de qualidade de vida: na medida em que não são capazes de se reproduzir em um mesmo patamar qualitativo (i.e., que sua reprodução inferior passe a constituir o caso padrão), passam a ofertar no mercado uma mercadoria cuja quantidade de horas necessárias para sua produção e reprodução é inferior àquela observada anteriormente. O resultado dessa queda do valor da força de trabalho é que o ganho de superexploração - associado com uma usurpação do tempo de trabalho necessário, uma "violação" da justa troca mercantil - desaparece, cedendo lugar para uma ampliação permanente na taxa de exploração.

Portanto, podemos afirmar que o ganho de superexploração é um subproduto da ampliação relativa de mais-valor que resulta da diferenciação entre salários e valor da força de trabalho. É um fenômeno temporário, um tipo de mais-valor adicional que surge de formas específicas de ampliar a taxa de exploração e que precede a redução da qualidade de vida da classe trabalhadora.

Desse modo, a tese de Marini apresentada no início deste artigo, de que o fundamento da dependência é a superexploração do trabalho, pode ser interpretada de duas formas:

Primeiro, que nos países ditos dependentes, os trabalhadores recebem salários inferiores ao valor da sua força de trabalho, e que nessa diferença reside a fonte do lucro da acumulação de capital ${ }^{38}$. Pelo fato da divergência entre salários e valor da força de trabalho ser

(37) Tal como seria o caso de uma súbita variação do valor de alguma mercadoria particular que compõe a cesta de consumo dos trabalhadores.

(38) Essa leitura seria, a nosso ver, compatível com a posição de Osorio $(2009,2013)$. 
efêmera, isso implica dizer que seus processos geradores estão sempre em atuação, ou seja, que em uma economia dependente os salários reais se encontram em permanente trajetória descendente e/ou a jornada/intensidade do trabalho em trajetória ascendente.

Segundo, que nas economias dependentes há uma primazia dessas três formas de ampliar a taxa de exploração sobre as demais ${ }^{39}$. Isso significa que a dinâmica da economia dependente apresenta algum entrave para a ampliação da taxa de exploração pelas vias que não geram a superexploração - ou ainda, que nas economias dominantes existe um entrave para a ampliação da taxa de exploração por essas três vias que geram a superexploração -, de modo que estes fenômenos seriam menos recorrentes.

Acreditamos que não cabe aos autores dependentistas atuais discutir qual das duas interpretações é mais fiel ao intuito original de Marini. Independente de qual seria sua posição, a teoria da dependência só é relevante se for capaz de explicar os fenômenos concretos que observamos, servindo de alicerce para a ação prática. Dessa forma, os esforços dos atuais debatedores devem se centrar em comprovar a veracidade ou não da tese de que "a superexploração é o fundamento da economia dependente" - em qualquer uma ou em ambas as interpretações.

Nesse sentido, vemos que o caminho a ser seguido pelos estudos da dependência passa pelo aprofundamento dos seguintes pontos:

Primeiro, deve-se averiguar, do ponto de vista lógico-abstrato, o nexo causal proposto por Marini entre essas duas possíveis leituras e a dinâmica da sociedade dependente, respondendo as questões "porque os salários reais possuem permanente trajetória descendente e a jornada/intensidade do trabalho permanente trajetória ascendente?", ou "quais são os entraves às outras formas de se ampliar a taxa de exploração?";

Segundo, faz-se necessário avaliar, ainda do ponto de vista teórico, se os efeitos dessa superexploração na lógica de acumulação dos países dependentes são compatíveis com a hipótese de Marini, qual seja, a de que a superexploração obstaculiza a transição dessas sociedades para economias capitalistas pautadas por formas de exploração menos perniciosas à classe trabalhadora.

Terceiro - e, talvez, o mais significativo -, é preciso analisar empiricamente se os fenômenos indicados por alguma das duas interpretações acima são observados nas economias dependentes.

Essas três tarefas legaremos para pesquisas posteriores.

\section{Referências bibliográficas}

ALBA, Víctor. Los subamericanos. México: Costa-Amic, 1964.

(39) Interpretação que se adequa ao sentido dado por Carcanholo (2013). 
Rodrigo Straessli Pinto Franklin

ANTUNES, Ricardo. A desertificação neoliberal no Brasil: Collor, FHC e Lula. 2. ed. Campinas, SP: Autores Associados, 2005 [2004].

ANTUNES, Ricardo. Adeus ao trabalho?: ensaios sobre as metamorfoses e a centralidade do mundo do trabalho. 13. ed. São Paulo: Cortez, 2008 [1995].

ANTUNES, Ricardo. Os sentidos do trabalho: ensaio sobre a afirmação e a negação do trabalho. São Paulo: Boitempo Editorial, 2015.

BAMBIRRA, Vânia. O capitalismo dependente latino-americano. 2. ed. Florianópolis: Insular, 2013 [1974].

BAMBIRRA, Vânia. Teoria de la dependencia: una anticrítica. México: Era, 1978.

CARCANHOLO, Marcelo Dias. (Im)precisões sobre a categoria superexploração da força de trabalho. In: ALMEIDA FILHO, Niemeyer (Org.). Desenvolvimento e dependência: cátedra Ruy Mauro Marini. Brasília: IPEA, 2013. p. 71-97.

CARDOSO, Fernando Henrique; SERRA, José. Las desventuras de la dialéctica de la dependencia. Revista Mexicana de Sociología, v. 40, p. 9-55, 1978.

COMMUNIST LEAGUE OF FRANCE. A program of action for France. In: TROTSKY, Leon; BREITMAN, George. Writings of Leon Trotsky [1934-35]. New York: Pathfinder Press, 1971 [1934].

CUEVA, Agustín. Teoría social y procesos políticos en América Latina. México: EDICOL, 1979.

KATZ, Frederico Jayme. Clamando no deserto: a tese do bloqueio. In: COLÓQUIO INTERNACIONAL DA SOCIEDADE DE ECONOMIA POLÍTICA LATINOAMERICANA, 4., 2008, Buenos Aires. Anais... Buenos Aires: SEPLA, 2008.

KATZ, Frederico Jayme. Questionando as teorias da dependência e da financeirização: o Brasil na encruzilhada do desenvolvimento do capitalismo. São Paulo: Plêiade, 2011.

MARINI, Ruy Mauro. Dialéctica de la dependencia. 5. ed. México: Era, 1981 [1972].

MARINI, Ruy Mauro. Subdesarrollo y revolución. 8. ed. México: Siglo XXI, 1977 [1969].

MARINI, Ruy Mauro. Subdesarrollo y revolución en América Latina. Investigación Económica, México, v. 29, n. 113, p. 87-104, jan. 1969 [1967].

MARX, Karl. O capital: crítica da economia política; livro primeiro - o processo de produção do capital. Tradução Rubens Enderle. São Paulo: Boitempo Editorial, 2013 [1867].

MARX, Karl. O capital: crítica da economia política; livro terceiro - o processo global da produção capitalista. Tradução Rubens Enderle. São Paulo: Boitempo Editorial, 2017 [1894]. 
MARX, Karl. Salário, preço e lucro. In: MARX, Karl. Para a crítica da economia política; Salário, preço e lucro; $O$ rendimento e suas fontes: a economia vulgar. São Paulo: Abril Cultural, 1982 [1865].

OSORIO, Jaime. Explotación redoblada y actualidad de la revolución. México: Itaca; Universidad Autónoma Metropolitana, Unidad Xochimilco, 2009.

OSORIO, Jaime. Fundamentos de la superexplotación. Razón y Revolución, Buenos Aires, v. 25, p. 9-34, 1 nov. 2013.

PERLO, Victor. American imperialism. New York: International Publishers, 1951.

ROZZOTTO, Jaime Díaz. El carácter de la revolución guatemalteca: ocaso de la revolución democrático-burguesa corriente. México: Ediciones Revista Horizonte, 1958.

SANTOS, Theotonio Dos. Imperialismo y dependencia. Caracas: Fundación Biblioteca Ayacucho, 2011 [1978].

SMITH, Tony. Globalisation: a systematic Marxian account. Boston: Brill, 2006. (Historical Materialism Book Series, v. 10).

SMITH, Tony. Technology and capital in the age of Lean production: a Marxian critique of the "new economy". Albany: SUNY Press, 2000. 